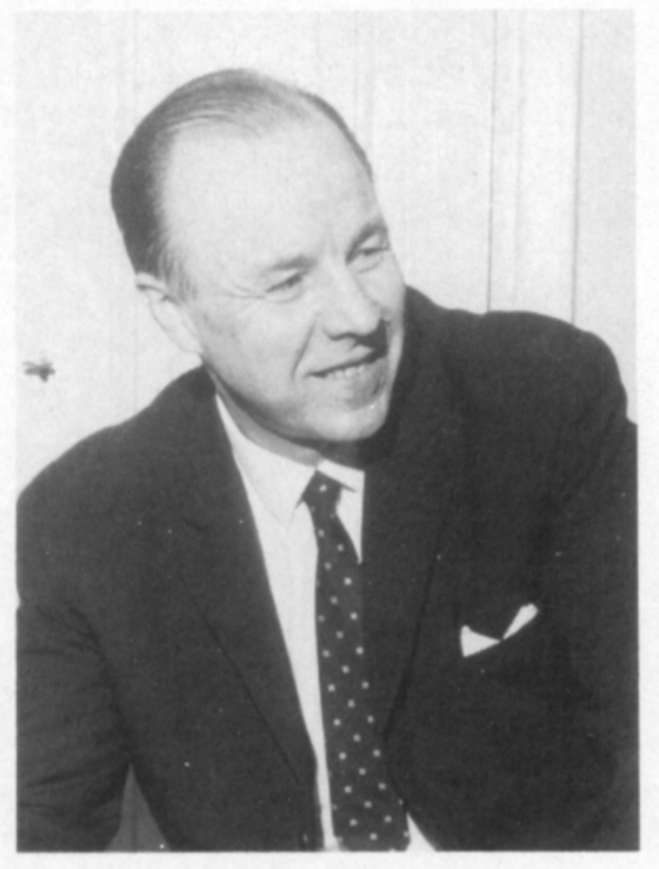

\title{
Professori Mikko Varo 70-vuotias
}

(Puhe syntymäpäivän kunniaksi järjestetyn symposiumin yhteydessä Helsingissä 27.9.1983)

\section{KALLE MAIJALA}

Maatalouden tutkimuskeskus, Kotieläinjalostuslaitos, 31600 Jokioinen

Helsingin yliopiston kotieläinten jalostustieteen professorinviran ensimmäinen haltija vuosilta 1966-76, maatalous- ja metsätieteiden tohtori Risto Mikko Varo syntyi Helsingissä 29.9.1913. Hän pääsi ylioppilaaksi Helsingin Maanviljelyslyseosta 1932 sekä valmistui agronomiksi ja maatalous- ja metsätieteiden kandidaatiksi 1940, pääaineenaan maanviljelysoppi. Hän toimi aluksi Etelä-Pohjanmaalla maanviljelyskonsulenttina, pika-asutustoimikunnan jäsenenä ja maanviljelyskoulun opettajana, mutta alkoi samalla suuntautua kotieläintieteisiin päin, suorittaen kandidaatintutkinnon laudatur-oppimäärän kotieläintieteessä 1946. Samana vuonna hän siirtyi maatalousministeriöön kotieläintoimiston päälliköksi ja syksyllä 1948 silloisen maatalouskoelaitoksen (nyk. MTTK) kotieläinjalostusosaston vanhemmaksi tutkijaksi. Hän väitteli syksyllä 1952 tohtoriksi kotieläinjalostusta koskevalla tutkimuksella ja sai nimityksen erikoistutkijaksi 1959.

Vuonna 1966 hänet määrättiin hoitamaan yliopistoon perustettua uutta professorinvirkaa, johon hänet nimitettiin seuraavana vuonna. Vuodesta 1954 
lähtien hän oli jo toiminut yliopistossa dosenttina kotieläinjalostuksen alalla. Hänen pääsasiallinen elämäntyönsä tapahtui siten tämän alan tutkimuksen ja opetuksen parissa, joissa hän virallisesti ehti toimia lähes 30 vuotta. Yli puolet hänen julkaisuistaan koski nautakarjaa, minkä lisäksi hän tutki sikojen, porojen, hevosten ja lampaiden jalostukseen liittyviä kysymyksiä sekä tarkasteli kotieläinjalostuksen yleisperiaatteita.

\section{Naudanjalostustutkimukset}

Varon työkausi kotieläinjalostusosastolla alkoi aikana, jolloin keinosiemennystoiminta oli juuri alkanut maassamme. Kun osaston tehtävänä oli huolehtia sonnien jälkeläisarvostelujen laskennasta ja kehittämisestä, hän näki välttämättömäksi selvittää, miten arvostelut olisi hoidettava keinosiemennyksen luomissa olosuhteissa, tyttärien ollessa hajallaan monissa pitäjissä ja kymmenissä karjoissa. Hän totesi myös tarpeen parantaa arvostelujen saantinopeutta ja luotettavuutta, jotta keinosiemennyskäyttöön voitaisiin saada perinnölliseltä laadultaan parhaita sonneja. Hän rupesi tutkimaan mahdollisuuksia käyttää hyväksi reikäkorttimenetelmää, aloittaen kokeilut 1949. Jo seuraavana vuonna saatiin ensimmäiset koneellisesti lasketut arvostelutulokset, jotka olivat olosuhteiden pakosta ns. tytärarvoja, koska emien tuotoksia ei ollut mahdollista saada. Emien sijasta otettiin vertailuperusteiksi karjojen keskituotokset, ilmaisemalla tyttärien tuotokset suhteellisina arvoina eli prosentteina karjojensa keskituotoksista. Täten voitiin eliminoida karjojen välisten ruokinta- ja hoitoerojen vaikutukset. Vuonna 1952 arvosteltiin 5300 sonnia, kun aikaisemmin oli käsityönä voitu arvostella vuosittain 100-200 sonnia.

Uuden arvostelumenetelmän käyttökelpoisuutta ja sen luotettavuuteen vaikuttavia tekijöitä Varo selvitti monissa 1950-luvulla ilmestyneissä tutkimuksissaan, erityisesti v. 1952 painetussa väitöskirjassaan "Tutkimuksia karjanjalostuksen tehostamismahdollisuuksista erityisesti sonnien valintaa silmälläpitäen”. Tässä hän osoitti suhteellisen arvostelutavan johtavan luotettavampaan tulokseen kuin kilomääräisen arvostelun. Hän totesi emä-tytärvertailun antavan tytärarvoja luotettavamman kuvan, mutta näki vertailun toteuttamisen käytännössä rïittävin tytärmäärin vaikeaksi. Väitöskirjassaan hän tarkasteli myös kysymyksiä lehmien tuotosten mittaustavoista ja korjaamisesta ulkoisten tekijöiden suhteen, tuotannon säännöllisyyden ja tyttärien lukumäärän merkitystä sekä vasikoiden valintaa ja valintamahdollisuuksien hyväksikäyttöä.

Myös vuosina 1953 ja -56 ilmestyneissä jatkotutkimuksissa jälkeläisarvostelun tuloksista erilaisessa ympäristössä osoittautui suhteellinen arvostelutapa käyttökelpoiseksi. Samanlainen johtopäätös saatiin, kun tutkittiin sonninarvojen luotettavuutta eri tuotostasoilla. Alemmilla tasoilla tosin tarvittiin suuremmat tytärmäärät kuin ylemmillä. Monissa maissa 1950-luvulla omaksuttu tapa käyttää vertailueläiminä vain karjan samanikäisiä lehmiä ei osoittautunut soveltuvaksi pieniin karjoihimme. Eri sonnien tyttärien erilaisesta karsiutumisesta kuuden vuoden ikään mennessä ei näyttänyt olevan sanotta- 
vaa haittaa arvostelun luotettavuudelle. Varo käytti jälkeläisarvosteluaineistoa myös karjojen välisten perinnöllisten erojen selvittämiseen ja lehmien perinnöllisen maidontuotantokyvyn edistymisnopeuden arviointiin. V. 1962 tehdyssä tutkielmassaan hän sai edistymisnopeudeksi $0.73 \%$ vuodessa.

Varon 1950-luvun alussa kehittämä sonnien koneellinen jälkeläisarvostelumenetelmä oli aikanaan ensimmäisiä alallaan maailmassa ja oli pääperiaatteiltaan Suomessa käytössä noin 30 vuotta. Ajanmukaisella sonnien jälkeläisarvostelulla oli suuri merkitys keinosiemennyksen tarjoamien mahdollisuuksien hyväksikäytölle lypsykarjamme perinnöllisen tason parantamisessa. Saadakseen menetelmän käytön tarkoituksenmukaiseksi Varo tarkasteli useissa yhteyksissä keinosiemennyssonnien valintaa ja laati näille asetettavia vähimmäisvaatimuksia. Hän kiinnitti tutkimuksissaan huomiota myös lehmien kestävyyden, terveyden ja hedelmällisyyden säilyttämistarpeeseen ja -mahdollisuuksiin sekä pyrki valitsemaan jalostusvalinnan perusteiksi sellaisia tuotantokyvyn mittoja, jotka varmistaisivat elinvoiman säilymisen. Hän tutki myös sonnien siemennystuloksiin vaikuttavia tekijöitä ja ns. rakkuloiden periytymistä sekä lehmien koon vaikutusta tuotoksiin ja kestävyyteen.

Maidon koostumuskysymyksiin hän joutui paneutumaan 1950- ja 1960lukujen vaihteessa, kun osasto aloitti Valion kanssa maidon valkuaispitoisuustutkimuksen. Lounais-Suomesta kerätystä aineistosta Varo löysi selviä eroja sonnien väliltä valkuaispitoisuuden periyttäjinä. Valkuaisen ja kuivaaineen periytyvyydet olivat kuitenkin heikompia kuin rasvapitoisuuden. Arvostelun varmuus riippui tyttärien ja määrityskertojen lukumäärästä ja valkuaispitoisuus myös tuotostasosta. Rasvapitoisuuteen kohdistunut valinta edisti myös valkuaispitoisuutta. Varo suositteli valintaperusteeksi kokonaiskuiva-ainepitoisuutta, kunnes valkuaisen määritysmenetelmät varmistuvat. Myöhemmin hän totesi valkuaisjalostuksen edellytysten olevan jo olemassa.

Naudanlihan tuotannon merkityksen lisääntyminen 1950-luvun lopulla nosti esiin kysymykset siitä, millä tavalla lihanantiominaisuudet kuten kasvukyky ja lihakkuus olisi otettava huomioon jalostustavoitteissa ja miten jalostustoimin voitaisiin edistää naudanlihan tuotantoa. Varo sai tehtäväkseen suunnitella jalostuksellisen puolen niissä lihanautojen kasvatuskokeissa, jotka osasto aloitti v. 1960 yhdessä Kotieläinhoidon tutkimuslaitoksen kanssa. Kokeissa selvitettiin toisaalta rotujen välisiä eroja, toisaalta myös sonnien poikaryhmien välisiä eroja. Kummassakin suhteessa löytyi eroja, etenkin rotujen väliltä. Kokeet koskivat lypsylehmien erirotuisista isistä peräisin olevien vasikoiden vertailuja, ja näissä suhteellisen voimaperäistä ruokintaa soveltavissa kokeissa charolais yleensä osoittautui kilpailukykyiseksi.

Lihantuotantotutkimuksissa Varo rupesi varsin pian kiinnittämään huomiota ruhojen koostumuksen ja teuraslaadun mittaamiseen. Selvittääkseen mahdollisuuksia mitata lihakkuutta ja rasvaisuutta eläviltä eläimiltä hän alkoi tutkia ultraäänimenetelmän käyttökelpoisuutta. Hänen johdollaan tehtiin yliopistokaudella ultraäänimittauksia erityisesti sonnien kasvatusasemalla ja julkaistiin tutkimuksia mittausten käyttöarvosta. Teurasruhoista tehtiin leikkelyanalyysejä teuraslaadun arvostelumenetelmien kehittämiseksi ja elävänä tehtyjen mittausten ennustusarvon selvittämiseksi. 


\section{Hevostutkimukset}

Varo aloitti hevosen vetovoiman kehittämismahdollisuuksia koskevan tutkimustoimintansa jo maatalousministeriössä ollessaan, julkaisten kaksi tutkimusta. Näistä ensimmäisessä hän kiinnitti huomiota tarpeeseen erottaa vetovoiman ja luonteen arvostelu toisistaan, tammojen vetovoimaluokittelun tehostamiseen sekä koeolosuhteiden vaihtelun vähentämiseen. Toisessa tutkimuksessa oli kysymys iän vaikutuksesta vetovoimaan sekä erilaisesta harjoituksesta, hoidosta, ruokinnasta ja koeolosuhteista johtuvien arvosteluvirheiden eliminointimahdollisuuksista.

Elopainon ja iän huomioonottamiseen vetovastusta kokeissa määrättäessä hän kiinnitti huomiota myös 11 vuotta myöhemmin julkaistussa tutkimuksessaan, todeten, että oriiden prosenttinen vetotulos alenee $2.4 \%$-yksiköllä, kun elopaino nousee 100 kilolla. Tästä syystä hän suositteli eri portaiden vetovastuksen tarkistamista siten, että se olisi oikeassa suhteessa hevosten todettuun vetokykyyn. Samalla hän suositteli suhteellisen vetovastuksen pitämistä rïppumattomana hevosen iästä. Vetokyvyn periytymisasteeksi hän sai $17 \%$. Hän ehdotti useaan kertaan kokeissa olleiden hevosten vetotuloksen laskettavaksi kaikkien kokeiden keskiarvona sekä että vetokoe palautettaisiin maksimikokeeksi, jolla hevosen suurin mahdollinen vetovoima on mitattavissa.

Varo tutki 1960-luvun alkupuolella myös tammojen kantakirjatietoja yli 10 vuoden aineistolla. Kantakirjapiirien väliset erot osoittautuivat erittäin merkitseviksi lähes kaikissa ominaisuuksissa ja ikäryhmissä. Suurin merkitys niillä oli yhteispisteissä, koepisteissä, käynnin arvostelussa ja rakennepisteissä, joissa ne selittivät yli $10 \%$ muuntelusta. Vetokyvyn arvostelussa oli piirien merkitys alle $4 \%$. Tutkituista 32 ominaisuudesta osoittautuivat selvimmin periytyviksi käynti- ja juoksunopeus sekä liikkeet, joiden kaikkien periytymisaste oli noin $40 \%$, kun suhteellisen vetovoiman vastaava luku oli $14 \%$ ja ruumiinmittojen 20-30\%. Kaikkien tutkittujen ominaisuuksien osalta todettiin jalostusvalinnalle olevan hyvät edellytykset periytyvyyden puolesta. Näillä työhevosen ominaisuuksien periytymisasteen arvioilla on ollut kansainvälistä merkitystä sen vuoksi, että ne ovat maailmassa lähes ainoita käyttökelpoisia arvioita työhevosen ominaisuuksille.

Varo tutki tamma-aineiston avulla myös hevosen jalostettavien ominaisuuksien keskinäisiä yhteyksiä, joiden nojalla hän saattoi faktorianalyysiä käyttäen jakaa ominaisuudet viiteen toisistaan lähes riippumattomaan ryhmään: vetovoima, nopeus, kokotekijä, lihavuustekijä ja jalkamitat. Rakenneominaisuuksien sijoittuminen suorituskykyominaisuuksista erillisiin ryhmiin vahvisti täten käsityksiä sïtä, ettei suorituskykyä voida jalostaa ulkonaisten rakennepiirteiden avulla. Oriaineistosta saadut tulokset olivat samanlaisia. 
Sikoja koskevat tutkimuksensa Varo aloitti 1960-luvun alussa, jolloin sikatalouskoeaseman koko kantakoeaineisto vietiin reikäkorteille 35 vuoden ajalta. Varo käsitteli koeryhmien keskitulokset faktorianalyysillä, jonka tuloksena saatiin 18 ominaisuudelle kolme yhteistä tekijää: rasvatekijä, kasvutekijä ja lihakkuus- eli rakennetekijä. Tekijät olivat toisistaan riippumattomia. V. 1962 julkaistussa tutkimuksessa arvioitiin myös ominaisuuksien periytymisasteet. Selkäsilavan paksuudelle arvio oli n. $50 \%$, ruhon painolle $30 \%$, lisäkasvulle 37 ja ruhon pituudelle $45 \%$. Arviot tulivat vahvistetuiksi myöhemmässä tutkimuksessa 1965 . Toisessa samanaikaisessa julkaisussa todettiin faktorianalyysin antaneen toiveita valinnan keskittämismahdollisuuksiin eräisiin muuntelua hallitseviin ominaisuuksiin.

Varon tutkiessa mahdollisuuksia perustaa karjujen jälkeläisarvostelu 16 jälkeläiseen, joilla kullakin olisi eri emä, hän totesi sukupuolen ja perinnöllisyyden yhdysvaikutukset niin vähäisiksi, että arvostelussa voitaisiin ilman suurta haittaa rajoittua vain toista sukupuolta oleviin jälkeläisryhmiin, mikä helpottaisi karjujen välisten erojen havaitsemista. Tulokselle voi pian tulla uutta ajankohtaisuutta, jos karjuporsaiden leikkaamisesta luovutaan ja sikojen arvostelutoiminnassa siirrytään pääasiassa karjuporsaiden käyttöön. Eräiden ominaisuuksien periytymisasteiden arvioissa oli tosin huomattavia eroja sukupuolien välillä.

Saatuaan 1970-luvun alussa käyttöönsä ultraäänilaitteen Varo tutki sen avulla mahdollisuuksia arvostella teuraslaatua eläviltä sioilta. Laitteen avulla voitiin mitata pitkän selkälihaksen poikkileikkauspinta-ala, ja tutkimukset osoittivat, että elävän sian arvostelussa voidaan päästä varsin luotettaviin tuloksiin.

\section{Lammastutkimukset}

Varon osallistuminen lammastutkimuksiin alkoi 1963, jolloin osasto käynnisti Lampaanjalostusyhdistyksen kanssa nuorten pässien kasvukokeen. Hänen tästä aineistosta tekemänsä analyysi osoitti, että ruhon lihamäärään ja -prosenttiin voimakkaimmin vaikuttava tekijä on eläimen koko. Suurimmat periytymisasteen arviot saatiin ruhon ja sen eri osien painoille sekä ruhosta saadun lihamäärän painolle ynnä pituus- ja korkeusmitoille. Kasvukokeissa olleiden pässien jälkeläisillä tehdyt kokeet osoittivat, että suomenlampaassa on runsaasti perinnöllistä muuntelua ominaisuuksissa, joilla on merkitystä lihantuotannossa. Saamiensa tulosten perusteella Varo katsoi, että pässien fenotyyppitestaus on Suomessa hyvin aiheellinen toimenpide. Kun kasvukokeet uudelleen 1970-luvun puolivälissä saatiin koekäyntiin, kokeiltiin koepässeiltä Varon johdolla lihakkuuden mittaamista elävinä.

Varo oli 1960- ja 1970-lukujen vaihteessa johtamassa myös koetta, jonka tarkoituksena oli selvittää norjalaismallisen pässirenkaan soveltuvuutta Suomen oloihin jälkeläisarvostelua silmälläpitäen. 


\section{Poronjalostustutkimukset}

Vuonna 1962 Varon tutkimuskenttä laajeni poroihin, kun osasto aloitti yhteistyössä Paliskuntain Yhdistyksen kanssa tutkimuksen porojen jalostusmahdollisuuksista, erityisesti lihanantikykyä silmälläpitäen. Hän joutui täten myös alan pohjoismaiseksi ja kansainväliseksi uranuurtajaksi. Määrätietoisen jalostustoiminnan puuttuessa oli poron todettu Suomessa jatkuvasti pienentyneen, kun parhaat eläimet oli myyty teuraiksi. Järjestetyssä kokeessa tehtiin poroista hyvin monia mittauksia ja tuloksien arviointeja. Keskimääräinen tiinehtymis- $\%$ vaatimilla oli 64 , vaihdellen suuresti vaatimien iästä ja painosta rïppuen. Vaatimien keskipaino oli $65 \mathrm{~kg}$, hirvaiden $90 \mathrm{~kg}$ ja vastasyntyneiden vasojen $5.8 \mathrm{~kg}$. Kasvunopeus oli parhaimmillaan kesällä, ja toisen kesän kasvu oli vain puolet ensimmäisen kesän kasvusta. Varo suosittelikin vasojen teurastusta lihaksi pääasiassa niiden ensimmäisenä syksynä. Porojen teurastilastot vuosilta $1968-82$ osoittavat, että vasojen teurastus- $\%$ on tänä aikana noussutkin noin $23 \%$ :sta lähes $50 \%$ :iin ja vanhempien porojen laskenut $30 \%$ :sta $15 \%$ :iin, joten suosituksella on ollut merkitystä. Varon ensimmäinen porotutkimus ilmestyi 1964, ja toisessa jalostusmahdollisuuksia koskevassa tutkimuksessa 1972 hän totesi porojen syyspainojen periytymisasteet tyydyttävän suuriksi yksilövalintaa ajatellen. Myös painon muutos talvella näytti olevan perinnöllisiin taipumuksiin perustuva piirre. Vanhempien valinnalla voitiin jälkeläisten painonkehitystä parantaa. Käytännön jalostustyöhön Varo suositteli rinnanympäryksen ja rungonpituuden summamittaa.

Varon johdolla tehtiin myös tutkimus vaatimien maidontuotannosta ja maidon osuudesta vasojen kasvuun. Vaatimien maidontuotantokyvyssä oli eroja, jotka osittain olivat yhteydessä vaatimien kevätpainoihin siten, että kookkailla emoilla oli pienimmät valkuaispitoisuudet. Varo katsoi tulosten osoittavan, että kasvutaipumuksen jalostamisessa on valinta perustettava painoon tai kokoon eikä maidontuotantoon. V. 1975 ilmestyneessä tutkimuksessa, joka perustui pitkin talvea teurastettujen porojen teurasruhojen tutkimiseen, kävi ilmi, että ruhojen vesipitoisuus nousi, kun taas rasva-, valkuais- ja tuhkapitoisuudet laskivat.

\section{Yleisluontoiset tutkimukset ja menetelmien kehittely}

Varsinkin yliopistokaudellaan Varo joutui tarkastelemaan eräitä jalostuskysymyksiä yleiseltä, useita kotieläinlajeja koskevalta kannalta. Suurin yleinen merkitys on kuitenkin ollut hänen panoksillaan eräiden menetelmien ja tekniikkojen käyttöönotossa ja soveltamisessa. Nykyaikaisen tietojenkäsittelyn edeltäjän, reikäkorttijärjestelmän hän otti jalostustutkimuksen käyttöön varhaisessa vaiheessa, 1940- ja 1950-lukujen vaihteessa, ennen muita Pohjoismaita ja useimpia muitakin kehittyneitä maita. Tekniikan käyttöönotto edisti suuresti sekä hänen tutkimuksiaan että niiden tulosten soveltamista käytännössä. Useimmilla muilla maataloustutkimuksen aloilla Suomessa alkoi atk:n käyttö varsinaisesti vasta noin 20 vuotta myöhemmin. 
Varo kuului myös maailman ensimmäisiin faktorianalyysiä käyttäviin kotieläinten jalostustutkijoihin. Menetelmä auttoi häntä selkiyttämään kokonaiskuvaa monien mitattujen tai tavoitteiksi otettujen ominaisuuksien joukosta mm. hevosilla ja sioilla, jotta jalostustavoitteiden valinnassa olisi mahdollista päästä yksinkertaisuuteen ja jalostustyössä sen kautta tehokkuuteen.

Turvautuminen osittaiskorrelaatioiden käyttöön auttoi häntä väitöskirjatyössään pääsemään oikeisiin johtopäätöksiin, joilla sovellutusten, erityisesti sonnien jälkeläisarvostelumenetelmän kannalta oli tärkeä merkitys.

Lihantuotantoa koskevissa tutkimuksissa hän pyrki nopeasti perusteellisiin ruhojen leikkelyanalyyseihin, voidakseen saada luotettavamman käsityksen eläinten teuraslaadusta ja sen parantamismahdollisuuksista kuin mitä oli saavutettavissa silmävaraisilla teurasarvosteluilla. Jotta teuraslaatua olisi päästy arvostelemaan eläviltä eläimiltä, hän ponnisteli määrätietoisesti, saadakseen käyttöönsä sen ajan parhaimman ultraäänilaitteen ja rupesi sitä heti saatuaan käyttämään eri kotieläinten lihantuotantokykyä koskevissa tutkimuksissa.

\section{Toiminta opettajana}

Ennen tuloaan yliopiston opettajaksi kotieläinjalostuksen alalla Varolla oli jo kokemusta opettajantyöstä, sillä hän oli opettajana Orismalan maanviljelyskoulussa 1944-46 sekä maatalouden tuntiopettajana Helsingin Opettajakorkeakoulussa 1948-60. Hän oli suorittanut kasvatusopin tutkinnon ja antanut hyväksytyt opettajanäytteet, joita harvoilla yliopiston dosenteilla ja professoreilla on. Alan dosenttina hän ehti toimia lähes 12 vuotta ja ensimmäisenä professorina, jonka tehtävänä oli luoda kotieläinten jalostustieteen opetusjärjestelmä ja tutkintovaatimukset, 10 vuotta. Näitä tehdessään hän saattoi käyttää hyväkseen 20-vuotista tutkijan- ja opettajankokemustaan ja siten välttää hapuiluvaiheen. Yliopiston professorina ollessaan hän jatkoi määrätietoisesti tutkimustöitään ja pystyi siten antamaan pääaineenaan kotieläinten jalostustiedettä opiskeleville mielekkäitä ja kasvattavia erikoistyön aiheita sekä opastamaan asiantuntemuksella näiden tekemisessä.

\section{Kansainvälinen toiminta ja yhteistyö}

Varo osallistui pohjoismaiseen yhteistoimintaan Pohjoismaiden Maataloustutkijain Yhdistyksen kotieläinjaostossa ja tämän eräissä työryhmissä, pitäen esitelmiä, sekä saamelais- ja poroasioita käsittelevässä pohjoismaisessa yhteistyöelimessä, pitäen esitelmiä poronjalostuksesta useissa pohjoismaisissa porosymposioissa. Hän osallistui myös pohjoismaisiin geneetikkokongresseihin. Niin ikään hän osallistui esitelmin useisiin Pohjoismaiden Taloudellisen Karjanjalostusyhdistyksen kokouksiin.

Hän osallistui useihin Euroopan Kotieläintuotantoliiton vuosikongresseihin ja piti niissä esitelmiä. Hän oli jäsenenä Suomen ja Neuvostoliiton välisen tieteellisteknisen yhteistyöelimen maatalousryhmässä, samoin vastaavissa 
Suomen ja Puolan sekä Suomen ja Unkarin välisissä maatalouden yhteistyöryhmissä. Hän toimi kansainvälisen porosymposion järjestelytoimikunnan puheenjohtajana 1971 ja samanlaisen keinosiemennyssymposiumin järjestelytoimikunnan puheenjohtajana 1973.

\section{Toiminta kotieläinjalostuksen käytännössä}

Käytännön pohjaa tutkijan ja opettajan uralleen Varo sai koulupoikana enonsa tilalla Laihialla, Itä-Karjalan sodanaikaisessa maataloushallinnossa, seuratessaan hevoshoidontarkastajaa orinäyttelyissä sekä urospuolisten kotieläinten tarkastuspakkotoimikunnan jäsenenä 1940-luvulla.

Tutkijana ja/tai yliopiston professorina ollessaan hän oli valtion keinosiemennystoimikunnan sihteerinä 18 vuotta, Sianjalostusyhdistyksen jalostusvaliokunnan jäsenenä 9 vuotta, Suomen Hippoksen 8 vuotta. Hän edusti kotieläintieteitä valtion maatalous-metsätieteellisessä toimikunnassa 1969-70 ja maataloustutkimuksen neuvottelukunnassa $1972-76$. Hän toimi valtion hevosjalostuslaitoksen johtokunnan varajäsenenä 1960-62 sekä Keinosiemennysyhdistysten Liiton tilastotoimikunnan jäsenenä 1964-66 ja Karjatalous-lehden toimitusvaliokunnan jäsenenä 1964-75. Hänet kutsuttiin Suomen Ayrshireyhdistyksen kunniajäseneksi 1971. Helsingin yliopiston rahastojen yhteyteen perustettiin hänen nimeään kantava stipeidirahasto 1976.

\section{Arviointi elämäntyöstä}

Professori Varon panos Suomen kotieläinjalostuksen kehitykseen muodostui painavaksi erityisesti naudanjalostuksessa hänen oikeaan aikaan kehittämänsä ja tehokkaan sonnien jälkeläisarvostelun ansiosta. Tällä oli huomattava merkitys myös kansainvälisen tieteen kehittymisen sekä maamme karjaaineksen kansainvälisen kilpailukyvyn kehittämisen kannalta. Poronjalostustutkimuksessa hän on ollut kansainvälinen uranuurtaja. Myös hänen työhevosen ominaisuuksien periytyvyyttä ja jalostusmahdollisuuksia koskevilla tutkimuksillaan on ollut huomattava kansainvälinen arvo, samoin hänen kotieläinten lihanantikykyä koskevilla ultraäänitutkimuksillaan. Hänen sikoja, poroja, hevosia ja lampaita koskevat tutkimuksensa ovat ratkaisevasti palvelleet näiden eläinlajien tarkoituksenmukaisuuden kehittämistä maassamme.

Selityksenä tutkimusten kansainväliselle ja kotimaiselle merkitykselle voidaan esittää professori Varon tutkijanasenteen perusteellisuus ja omaperäisyys, sitkeys töiden loppuun viemisessä sekä vastuksia ja arvostelua pelkäämätön rohkeus oikeiksi katsomiensa periaatteiden käytäntöön viennissä. Hän on täyttänyt tärkeän paikan Suomen kotieläinjalostuksen sekä sen tutkimuksen ja opetuksen historiassa. On vaikea kuvitella esim. Suomen nautakarjan keinosiemennysjalostuksen kehitystä ilman hänen panostaan. Hänellä on ollut halua ja kykyä valita tutkimuskohteikseen tärkeitä kysymyksiä ennen kuin käytäntö on ehtinyt niitä vaatia. 
The first holder of professorship in animal breeding at the University of Helsinki (1966-1976), Risto M i k k o Varo, D.Sc. (Agr. and For.) was born in Helsinki on September 29, 1913. He was appointed researcher at the Department of Animal Breeding of the present Agricultural Research Centre in 1948. After receiving his doctor's degree in 1952 Prof. Varo held faculty positions at the University of Helsinki, where he was appointed docent in 1954 and professor in 1966. He was engaged in animal breeding research for about 30 years, publishing studies on cattle, horses, pigs, sheep and reindeer.

Prof. Varo made an important contribution to the development of cattle breeding in Finland and other countries by developing a method of progenytesting AI bulls with a punch-card system in 1950 . He applied daughter records instead of dam-daughter comparisons and introduced comparisons with herd averages. He tested the usefulness of the method in different environments and on different herd yield levels and the effect of culling of daughters on the reliability of the tests. The method was in use in Finland for about 30 years. He also studied problems related to longevity, fertility, milk composition and meat production. In the latter problem he applied Scanogramme ultrasonics.

Prof. Varo further studied heredity of working performance in the Finnish horse, allocating the traits to five independent groups with the factor analysis. In pigs he estimated heredity of traits measured at a litter testing station, allocating them to three groups with the factor analysis. He investigated the possibilities of progeny-testing AI boars in the field and applied Scanogramme ultrasonics to evaluating live pigs for slaughter quality. In sheep he applied ultrasonics to studying meat and growth traits. Finally, Prof. Varo was the first researcher to study the possibilities of genetic improvement in reindeer. 